\title{
HIGHER EDUCATION AND YOUTH PREPARATION FOR THE LABOUR MARKET: THE CASE OF UNIVERSITIES
}

\author{
DR. A. A. ADEOGUN \\ E-mail: aadeogun2005@yahoo.co.uk \\ DR. S.A. OYEBADE \\ E-mail: oyebadestephen@yahoo.com \\ G. I. OSIFILA \\ E-mail: osifilagboye2002@yahoo.co.uk
}

Department Of Educational Administration

Faculty Of Education, University Of Lagos, Lagos - Nigeria

\begin{abstract}
This paper examines the role of higher institutions of learning, especially university, in preparing youth for the labour market. Human capital formation has been described as a pre-condition for the success of any nation. One important institution that entrepreneurs in both public and private sectors of the economy rely on for the production of high level manpower is the university. However, evidences have shown that a large mismatch appears to exist between university output and labour market demand. There is an abundance of university trained labour, but the most worrisome feedback from employers of Nigerian graduates is just how serious quality deterioration has become. Most employers observe that the qualities of university graduates have worsened. This paper, therefore, examines the ideal role of universities, the causes of quality deterioration in Nigerian universities and strategies to solve the prevailing problems in order to prepare and produce quality graduates for the labour market in Nigeria.
\end{abstract}

Key words: Higher education, youth preparation, labour market, universities, funding, facilities, minimum academic standards, internship and student work study.

\section{Introduction}

Education is obviously the basic instrument of economic growth and technological advancement of any society. It is in recognition of this that governments commit immense resources to ensure the provision of education for their citizens. However, an educational system that worth its salt is that which emphasizes quality, relevance, accessibility and equity in education. And quality education connotes that a product of an educational system must be equipped with the necessary knowledge, skills and competencies to function effectively in the competitive world and to be able to face the realities of life.

Today, the world's workplace is becoming increasingly geographically fluid across national, regional and international borders due to economic globalization and the development of advanced communication and information technologies. In this context, knowledge has emerged as an economic commodity which has in turn placed pressure 
on existing national systems to ensure they are placed competitively in the international marketplace. Therefore, qualitative university education is acknowledged as a vital driving force for the acquisition of this knowledge or skill (Oyebade, Oladipo and Adetoro, 2007).

The central goal of any university education is to prepare the students for productive employment. Such employment can be paid one or self-generated. The connection between education and employment is, however, not automatic. It depends on several considerations. The first is the extent to which education attributes are congruent with labour market parameters. The second is the extent to which education is adaptable to the emerging dynamics in the labour market. The third is the speed with which investments, hence jobs, are generated in the economy, and the last is the efficiency with which job seekers (graduates) and job givers (employers) sort out their demands and 122 expectations resulting in job offers. When any or a certain combination of the above conditions is not met, what emerges is the phenomenon of unemployment and/or underemployment.

The big questions, however, are: are university graduates in Nigeria adequately educated for the labour market? This question is hotly debated by the public and the press in particular. It is a question of particular concern to graduates who are seeking employment and to employers who consider hiring them. Also, how do employers assess the qualifications of current degree-holders and how well do graduates perform when they are able to obtain employment?

These concerns have prompted this paper. It seeks to answer these and trace the ideal role of universities, causes of quality deterioration in the pursuit of students' preparation for the world of work and the remedies that can be adopted to ameliorate or exterminate the ugly trend of producing "half-baked" graduates.

Learning at the tertiary level of education could be described as being effective if it results in bringing about the expected transformations in the attitude, skills and knowledge of higher education students over a period of time. Moreover, effective learning should result in producing graduates who are adequately informed, technically equipped and morally prepared to become productive workers, self-reliant entrepreneurs, responsible parents, good citizens, selfless leaders ... (Babalola and Jaiyeoba, 2008).

The method adopted in this paper is discursive, borrowing extensively from a variety of documentary evidence, research analyses and book summaries, across the spectrum of conventional and non-traditional education offerings, collaborative initiatives and various seminal works.

\section{The Problem}

Many writers assertion of ineffective learning in higher education has become a major concern in Nigeria for so many reasons. Firstly, the concerns about poor learning in Nigerian tertiary institutions amplify as many of the Nigerian youth found it increasingly difficult to gain employment in the formal sector or end up working in poor conditions in the informal economy. Secondly, ineffective learning becomes a prominent suspect as scientific facts increasingly reveal that tertiary education graduates in Nigeria acquire skills in discipline such as Economics, Law and Medicine that are neither demanded by 
the labour market nor required by the economy especially in the growth sectors such as petroleum, gas, agriculture, manufacturing, solid minerals, tourism and ICT (Federal Ministry of Education, 2005 and Babalola, 2007).

Thirdly, increasing scientific evidences about employers' complaints regarding poor graduate preparedness. For instance, Dabalen and Oni (2000), in a survey of 55 public enterprises in Nigeria revealed that employers complained that skills of Nigerian graduates had steadily deteriorated between 1990 and 2000 and therefore these graduates have become increasingly unproductive on the job.

Furthermore, beyond general agreement regarding falling standards of university education, many employers cited key skill areas as particularly worrying. Two of these skills were communication and technical proficiency, poor abilities in the oral and written expression of English were mentioned almost like a chorus. Inadequate preparation in the English language was especially noted by newspapers and businesses where regular report writing is required.

The other skill area of great concern to employers is the technical preparation of graduates. Although many employers confirm that the graduates possess a broad and respectable understanding of the knowledge base in technical disciplines, they expressed disappointment with the preparation of the graduates in those applied technical skills necessary for solving problems and enhancing business productivity (Scholar, 2004).

Also, it is reported that employers often stated that graduates had not been exposed to equipment used in the workplace even when such equipment is quite conventional. Graduates were also reported incapable of technical solutions to routine problems as expected of individuals with their levels of training. As a consequence, a number of firms, especially larger ones with some investment capital, put their recruits through intensive post-employment training to prepare them for their responsibilities in the work place.

\section{Ideal Role of Universities}

Various writers have discussed the nature of the emergence of universities across the globe, especially with respect to their beginnings, and purpose. Writing on the nature of such beginnings, Cox (2006) and Barnet (1990) have noted that universities emerged out of a need for junior and older scholars to search for knowledge, identify a forum for testing out their theories and ideas (Adekanmbi, 2007).

As opined by Ogundimu (1988), the traditional roles of Nigerian universities have been the training of manpower for public administration, the professions and corporate needs.

In the words of Ajayi (2003), university education is geared towards serving as power houses and think tanks for the continuous advancement of knowledge, the generation of innovative ideas, the development of the minds of the young and the old (through engagement in challenging intellectual work) and continuous engagement in issues concerning the survival of humanity.

Biobaku (1975) cited in Ekeh (2003) sees the role of universities as a basic necessity which helps countries to rip of poverty, ignorance and disease. Universities achieve this through the inculcation in young people of requisite knowledge and skills in science, technology, arts and humanities. By so doing, university education ensures that 
qualified manpower is produced for proper management and development of different sectors of nation's economy, including education, health, transportation and industries.

In line with the foregoing, the Federal Government of Nigeria (FGN, 2004) declared succinctly in the National Policy on Education as follows:

The goals of tertiary education shall be to:

- contribute to national development through high level relevant manpower training;

- $\quad$ develop and inculcate proper values for the survival of the individual and society;

- $\quad$ develop the intellectual capability of individuals to understand and appreciate their local and external environments;

- $\quad$ acquire both physical and intellectual skills which will enable individuals to be self-reliant and useful members of the society;

- $\quad$ promote and encourage scholarship and community service;

- $\quad$ forge and cement national unity; and

- $\quad$ promote national and international understanding and interaction (Section 8: 59)

Specifically, Section $64 \mathrm{a}-\mathrm{c}$, specifies that university education shall make optimum contribution to national development by:

- $\quad$ intensifying and diversifying its programmes for the development of high level manpower within the context of the needs of the nation;

- making professional course contents to reflect our national requirements; and

- $\quad$ making all students, as part of a general programme of all-round improvement in university education to offer general study courses such as history of ideas, philosophy of knowledge and nationalism.

It is expected that these goals shall be pursued through teaching, research and development, generation and dissemination of knowledge and maintenance of minimum educational standards through appropriate agencies.

Constraints Facing Effective Preparation of University Graduates in Nigeria The challenges of universities in Nigeria are enormous and have been catalogued by different scholars. These challenges include the following:

\section{Funding}

This is major problem confronting the ability of universities to produce well-trained graduates (Tamuno, 1987; Akinkugbe, 2001; Babalola, 2001; Ade-Ajayi, 2003). For instance the Committee of Vice-Chancellors (CUC) of the Nigerian Federal Universities in a communiqué issued at the end of their regular meeting in 2001 indicated that the university system is in crisis due to under-funding. The fallout is that many projects are stalled, abandoned or put on hold while salaries of staff are delayed. Oke (2001) identified inadequate funding of capital projects at the Ladoke Akintola University of technology as a major problem that made it extremely difficult to put in place the much needed basic physical infrastructure for teaching, research and consultancy services. 
Aina (2007) observed that the Federal Government has starved the universities of funds providing less than $51.7 \%$ of the funds required.

Furthermore, Akpotu (2005) reports that universities, both federal and state owned are being starved of funds at the time when the existing physical facilities are ageing fast and are operating in adverse conditions of overcrowded classrooms, pitiable hostels and deteriorating physical facilities. The lack of funds and such related issues have led to prolonged crises, closure and brain drain.

\section{Staff-Related Problem}

There is no doubt to state that poor quality staff produces poor quality graduates. Although most employers are unhappy with the quality of graduate output from the federal universities, they are well aware of the causes. Many employers are quick to state that the quality of the graduates is simply a reflection of the quality of academic staff, learning resources (libraries, laboratories etc.) and funding limitations.

The decline of staff quality is reflected in the high rates of "brain drain", the declining number of professors and associate professors within the university system, and their falling levels of postgraduate preparation. In addition, as students' enrolments have doubled, the numbers of qualified instructors have not kept pace. As a result, staff/student ratios have worsened to the detriment of student learning.

\section{Shortage of Learning Materials}

Poor quality of graduates is also caused by a shortage of learning resources. Many university libraries are reported to hold out of date collections. One respondent for a manufacturing firm noted that even the instructors from some of the local universities whose graduates they recruit do not have copies of basic texts that are available in the corporate library and essential reading for the engineering processes used by the firm (World Bank/NISER, 2003).

\section{Industrial Conflicts in Nigerian Universities}

In Nigeria, several forces or factors within and outside the university system combine to make its calendar unstable. In increase spate of industrial unrest by academic staff contributes to poor quality of graduates. According to Imhabekhai (2001), industrial conflicts have become prevalent in various higher institutions of learning in Nigeria. In Nigerian universities for instance, the Academic Staff Union of Universities (ASUU) has called its members out on nationwide strike for about six times between $1992-2001$.

Buttressing the above position, Egbokhare (2001) confirms that "during this period (1992 - 2001), universities have lost about three years. If we add the period of strike by student, Senior Staff Association and Non-Academic Staff Union, universities may as well have lost four years or more within the last decade. Bureau for Public Opinion (Ubong, 2002) indicates that a result of research covering the period $1990-2000$ highlighted the following facts:

- $\quad$ Nigerian universities were closed for 3 years, 5 months in the 10 -year period;

- ASUU strike-induced closure accounted for 2 years, 7 months of the 3 years, 5 months; and 
- Cultism-induced closure accounted for 5 months while students' unrest took 3 months, 2 weeks.

This implies that ASUU-induced strikes accounted for approximately $79 \%$ of the period of closure of universities in 10 years.

Regarding this incessant strikes, critical views both within and outside Nigeria universities, however, indicate that long strikes by university unions have had rather damaging effects on the system. These include the loss of academic sessions, irredeemable distortions in university calendar, longer than normal duration of academic programme and distractions from teaching and research by staff and students (Onyeonoru, 2004). From this viewpoint, strikes are destructive and within the university context they constitute inflicting problems on graduates' quality.

\section{Poor Research}

Saint, Hartnett and Strasser (2003) observed that as university autonomy was usurped by government, incentives and rewards for research productivity, teaching excellence and associated innovation gradually disappeared. In consequence, research output dropped, educational quality declined and poorly-trained graduates emerged. Hartnett (2002) indicated low levels of investment in research and education. For instance, only $1.3 \%$ of the overall budget of Nigeria's Federal University system budget was spent on research. According to Babalola (2001), the perceived dysfunction in Nigerian universities as observed by Babalola (2001) indicates a crisis situation with less money on teaching, research and community services. The foregoing scenario is a source of concern because of its possible implication of the quality of graduates produced.

Also, Nwuke (2003) has examined a number of challenges including low enrolment figures, funding, quality assurance, lack of adequate information technology, problems with governance and the inability of many of the universities to be market relevant. Olukoshi and Zeleza (2004) also identify among others multiple challenges for African universities noting the general rapid transformations from within and outside the universities, an improper interpretation of the mission of universities, the overreaching effect of globalization and the notion and application of governance.

\section{Strategies to Produce Quality Graduates in Nigerian Universities}

\section{Adherence to Minimum Academic Standards (MAS)}

According to the National Universities Commission (NUC) (1989), the purpose of the Minimum Standards in Nigerian universities is to "ensure that certain minimum level of competency is attained by graduates in any particular discipline at the end of their training". The Minimum Standards for Nigerian Universities requires the following:

- $\quad$ minimum course contents in each academic program;

- $\quad$ minimum floor space for lecture and laboratory facilities per student;

- $\quad$ minimum amount of laboratory space, library and other facilities per students; as well as

- a minimum staff - student ratio for effective teaching and learning in any particular discipline.

To ensure compliance with minimum academic standards, accreditation of courses must 
be regular and in-depth. The NUC (2001) explains that the accreditation process has "quality improvement as its main focus". The objectives are to:

- $\quad$ ensure that at least the provisions of the Minimum Academic Standards documents are attained, maintained and enhanced in the universities;

- $\quad$ assure employers and other members of the community that Nigerian graduates of all academic programmes have attained an acceptable level of competency in their areas of specialization; and

certify to the international community that the academic programmes offered in Nigerian universities are of high standards and that graduates are adequate for employment and further studies.

\section{Adequacy of Funding}

Adequate funding is a basic thing that must not be toyed with if universities intend to produce graduates that can stand the test of the time in their chosen fields or profession. Governments at state or federal level must evolve a strategic funding pattern for universities under their jurisdiction. Financial autonomy must be given to the university to charge appropriate students' levies or fees. The government can also support by offering consultancy services to the university in different areas. There is also the need for individual university to pursue the strategy of generating funds through other legal means to complement whatever they could get through subventions.

\section{Physical Facilities/Learning Resources}

With adequate funding physical facilities and learning resources are likely to improve. This is where the issue of procurement and maintenance of the facilities is very crucial. The university must put in place, functional facilities. In this regard as well, university can reach out to the community (private individuals, philanthropists, Non-Governmental Organizations, companies/corporate bodies) to assist them with provision of facilities. University can equally institute endowment funds.

\section{Linkages with the Labour Market}

There must be a closely knit relationship between the universities and the companies, industries or public and private sectors. Through this the university will identify their needs and tailor their programmes to suit those needs. With this, not only will their products be easily absorbed, they are likely to create jobs and profits from such business could be ploughed back to aid research in the university. Also, industry - university collaborations on projects open up opportunities for enhancing the education of students, developing and putting technologies to practical use.

\section{Research and Specialized Courses}

As Olaleye (2006) pointed out, "there is bound to be dissonance between the nature and quality of education provided and the needs of evolving societies, unless educational systems are well managed and oriented towards research, they will become obsolete, wasteful and irrelevant to the changing national needs.

The advanced countries have institutionalized high utility research and development $(\mathrm{R}$ \& D) programs in which as much as $1-3 \%$ of the national GDP has historically been 
invested (M.T.C, 1999). Using 2002 UNESCO data, the developed countries, with only $19.3 \%$ of the global population, spent $\$ 540.40$ per person on research; the developing countries with $69.3 \%$ of the global population spent $\$ 42.80$ per person, while the lessdeveloped countries with $11.1 \%$ of the global population spent $\$ 0.70$ per person. Also, in the United States, about $60 \%$ of all research in academia is federally funded (Iyang, 2008). Nigerian government should follow this laudable footstep.

Also, there should be establishment of specialized universities of agriculture, science, technology and humanities. By such arrangements, the growing areas of specialization will be easily catered for.

\section{Promotion of Competition in the Universities}

128 Competition, as much as necessity, is the mother of invention. However, without the promise of satisfaction, laurels and prizes, competition lulls and professional talent resides in latency. Motivations for engagement in research are not limited to financial rewards. Perceptions about the potential impacts of one's efforts, in the grander scale of things, affect the degree of motivation of an individual (Iyang, 2008). There should be the creation of reward systems for high-performing institutions and researchers, and the provision of basic infrastructure for talented groups or individuals at tertiary institutions with the requirement that they must produce.

\section{Collaborative Arrangement with Private or Public Sectors}

Nigeria's federal and state governments should not serve as the sole sponsor of any Nigerian university. The balance of support for students, physical infrastructure and some programs should come from the private sector and each university's entrepreneurial activities. Universities should expand campaigns for named endowments, grants, scholarships to provide opportunities for students. Meaningful internships should be extended to government agencies. Nigerian universities should reach out to foundations and institutions in both advanced and developing countries to establish consortia, partnerships, exchanges and research collaboration.

\section{Internship and Student Work Study}

The introduction of internship and student work study should be given more attention for the preparation of youths for labour market. This will provide opportunities for students to be aware of the challenges ahead of them in their disciplines. Adeyemi (2008), reported that in a national survey conducted, employers and business organizations are more likely to extend job offers to seventy percent (70\%) of their interns. He said that in 2006-2007, employers offered jobs to sixty seven percent (70\%) of interns that have served with them. Domingo (2008) said, there are indications that full time recruits coming out of internships are more successful as employees than those drawn from outside of the internship process.

The full-time undergraduate should have Students' Industrial Work-Experience Scheme (SIWES) as normal part of their training. This will prepare them appropriately for the demands of labour market. 


\section{Introduction of Information and Communication Technology (ICT)}

A good number of scholars have expressed the belief that ICT integration in education would yield bountifully (Wilderotter, 2007; Yusuf, 2005; Daniel, 2002). Wheeler (2000) noted that ICT is intended to serve as a means of improving efficiency in the educational process and effect changes in the teaching methodology, assessment of learning, student tracking, communication and evaluation. Other areas include research, community outreach, library and information services and management. Thus, integration of ICT by Nigerian universities will enhance positively the production of skillful graduates.

\section{Recommendations}

The need for higher institutions of learning to prepare the youth for the labour market desires greater attention to avoid high rate of youth unemployment. It has been observed that a large mis-match appears to have existed between university graduates and labour market demand. Therefore, higher education should ensure compliance with minimum academic standard, secure and generate adequate funds, procure and maintain adequate facilities for teaching and learning, develop a close relationship with companies, industries, public and private sectors, conduct researches, introduce specialized courses, promote competition among universities, introduce information and communication technology (ICT), develop a reward system for high performing institutions, researchers and students, encourage proper mentoring of students by lecturers and cohort advisers. Higher institutions should introduce internships and work study as part of normal training for all categories of students. Efforts should be made to design programmes relevant to our societal needs.

\section{Conclusion}

The need to make university education relevant to the needs and aspirations of the people necessitate the concept of Minimum Academic Standards and accreditation process. There is then the urgent need for relevant educational agencies of government to reinvigorate their efforts to ensure quality assurance in this regard. In this sense, Ajayi (1999) asserts that:

The major test of quality in our education is its relevance to the needs of the community. The thrust of education must be to meet the needs of daily life, the hopes of tomorrows and preparation for a largely unknown future".

Thus, the task of making our university to produce quality graduates for the labour market is a task for all and sundry.

\section{References}

Ade-Ajayi, J. F. 2003). "Development of university education". Paper presented at the University Stakeholders' National Consultative Forum. Abuja: FME, 1 - 4.

Adekanmbi, G. (2007). "Tertiary distance education in Africa: A response to trends in world higher education". Lead paper presented at second HERPNET conference at IITA Ibadan, 13th - 16th August.

Adeyemi, M. (2008), Internship as stepping stone to full-time Employment, Appointment and Management. The PUNCH, Wednesday, May 28. P.23. 
Aina, O. I. (2007). "Alternative modes of financing higher education in Nigeria and implications for university governance”. In J. B. Babalola and B. O. Emunemu (Eds.) Issues in higher education: Research evidence from Sub-Saharan Africa. Lagos: Bolabay Publications.

Ajayi, K. (1999). "Quality and funding of higher institutions of learning in developing countries: Nigeria as a case study”. Occasional Publication Series, Series No. 5, March, Federal College of Education, Abeokuta.

Ajayi, K. (2003). "Minimum standards and accountability in university education". In B. A. Eheazu and U. M. O. Ivowi (Eds.) Minimum standards and accountability in the Nigerian educational system. Port-Harcourt: Nigerian Academy of Education.

130 Akpotu, N. E. (2005). "Deregulating the Nigerian university system: Implications for equity and access". In G. O. Akpa, S. U. Udoh and E. O. Fagbamiye (Eds.) Deregulating the provision and management of education in Nigeria. Jos: NAEAP.

Babalola, J. B. (2001). "University funding, responses and performance under a declining economy in Nigeria”. Research and Seminar Series. Educational Planning and Policy Unit, Department of Educational Management, University of Ibadan.

Babalola, J. B. (2007). "Reform and development in Nigeria's tertiary education: Focus on the Obasanjo's administration”. In J. B. Babalola (Eds.) Access, equity and quality in higher education. Jos: NAEAP Publication.

Babalola, J. B. and Jaiyeoba, A. O. (2008). "Curriculum development for effective learning in higher education during knowledge and digital revolutions: The Nigerian experience". Departmental lecture in honour of Professor Ikechukwu Ukeje, Department of Educational Management, University of Ibadan.

Barnet, R. (1990). The idea of higher education. Buckingham: SRIII and the Open University Press.

Cox, V. (2000). http//www.geocities.com/noelcox. Accessed 20 March 2003.

Daniel, J. (2002). "Information and communication technologies in teacher education: A planning guide". Foreword. Paris: A division of Higher Education, UNESCO.

Egbokhare, F. (2001). "Academic Staff Union of Universities albatross". The Scholar, 16 -19 .

Ekeh, P. U. (2003). "Accountability in university education in Nigeria: The case of students' indiscipline". In B. A. Eheazu et al (Eds.) Minimum standards and accountability in the Nigerian educational system. Port-Harcourt: Nigerian Academy of Education.

Federal Government of Nigeria (2004). National policy on education. Lagos: NERDC Press.

Federal Ministry of Education (FME) (2003). Education sector status report. Abuja: FME.

Hartnette, T. (2002). "Financing trends and expenditure patterns in Nigerian federal universities: An update". Unpublished Report. Washington, DC: The World Bank. 
Imhabekhai, C. I. (2001). "Conflict dimension in higher education personnel management". In N. A. Nwagwu, E. T. Ehiametalor, M. A. Ogunu and M. O. N. Nwadiani (Eds.) Current issues in educational management in Nigeria. Benin City: NAEAP.

Iyang, H. I. (2008). "Aligning universities for excellence in sustainable development, research and education”. Distinguished guest lecture. Delivered at Julius Berger Auditorium, University of Lagos, Nigeria, 24 July, 2008.

Massachusetts Technology Collaborative (MTC) (1999). Analysis of the impact of federal R \& D investment scenarios on economic growth. Boston: MTC.

National Universities Commission (2001). Annual report. Abuja: NUC.

National Universities Commission (NUC, 1989). Approved minimum standards in education for all Nigerian universities. Lagos: NUC.

Nwuke, K. (2003). "Higher education, economic growth and information technology in Africa: Some challenges and issues". In B. M. Koyakou, B. Oyeyinka-Oyelaran and M. Rao. (Eds.) Africa dot Edu: Its opportunities and higher education in Africa. New Delhi: McGraw Hill Publishing Company Limited, 17 - 42.

Oke, O. (2001). The birth and development of Ladoke Akintola University of Technology. Ibadan: Science and Technology Development Foundation.

Olaleye, F. O. (2006). "The relevance of the university in Nigerian educational development". A paper presented at a conference at Enugu State University of Science and Technology, Enugu, March.

Olasi, J. (2008), Internship as stepping stone to full-time Employment. Appointment and Management. The PUNCH, Wednesday, May 28. P.23.

Olukoshi, A. and Zeleza, P. (2004). "Introduction: The struggle for African universities and knowledge". In P. Zeleza and A. Olukoshi (Eds.) African university in the twenty-first century, Vol. 1, Dakar: CODESRIA.

Onyeonoru, I. (2004). "Industrial conflict in Nigerian universities: The presence of the past and the thrust of the future". The National Scholar. Ibadan: ASUU Publication.

Oyebade, S. A., Oladipo, S. A. and Adetoro, J. A. (2007). "Determinants and strategies for quality assurance in Nigeria university education". Paper presented at second HERPNET conference at IITA Ibadan, 13th - 16th August.

Saint, W., Hartnett, T. A. and Strasser, E. (2003). "The determinants of national innovative capacity". Working Paper No. 7876. Cambridge, MA: National Bureau of Economic Research.

Tamuno, T. K. (1987). "Management of the universities in Nigeria: A look at the past, the present and the future". Proceedings of the $N U C / C V C / B C$ International Seminar. Zaria: Ahmadu Bello University.

The National Scholar (2004). "Employer's assessment of graduates in the mar- 
ket place". Excerpts from "Labour market prospects of university graduates in Nigeria (The World Bank/NISER Document)" ASUU Publication, June.

Ubong, B. (2002). "Unionism and quality assurance in tertiary institutions". In O. E. Ekpo and U. M. O. Ivowi (Eds.) Unionism and academic productivity in the Nigerian system. Proceeding of the $17^{\text {th }}$ Annual Congress of the Nigerian Academy of Education, $56-68$.

Wheeler, S. (2000). "The role of the teacher in the use of ICT". Keynote speech delivered at the National Czech Teachers' Conference, University of Western Bohemia, May 20, 2000.

132 Wilderotter, M. (2007). Microsoft Corporation. http.//www.school.zal PILP/welcome.htm.

Yusuf, M. O. (2005). "An investigation into teachers' self-efficacy in implementing computer education in Nigerian secondary schools". A Middle School Computer Technologies Journal 8(2). 